\title{
IX. An account of the life and writings of Lavoisier
}

\section{Jerome Lalande}

To cite this article: Jerome Lalande (1801) IX. An account of the life and writings of Lavoisier , Philosophical Magazine Series 1, 9:33, 78-85, DOI: 10.1080/14786440108562671

To link to this article: http://dx.doi.org/10.1080/14786440108562671

$$
\text { 曲 Published online: } 18 \text { May } 2009 .
$$

Submit your article to this journal

LII Article views: 2

Q View related articles $\asymp$ 
4. The two kings grant a freedom of trade reciprocally to the people of both nations.

"Peace being thus eftablifhed, the two kings behaved very friendly towards ea:h other, fmoked tobacco together, converfing on indifferent fubjests, and thought no more of the unfortunate wretches who during this campaign had been taken prifoners, and, of courfe, fent into havery; they remaining in the power of thofe by whom they had been captured. This war had colt on either fide about a thoufand tnen, feveral villages and towns being laid wafte, and fome thoufands of inhabitants deprived of their habitations and property. On the 2oth of Auguft the treaty was ratified, and on the 28 th we returned to the $\mathrm{king}$ in the capital.

[To be continued.]

1X. An Account of the Life and Writings of LAvoIs IER. By JEROME LALANDE.

Anthony Laurence Lavoisier was born at Paris on the 26th of Auguft 1743, and enjoyed the advantage of a good education, on which his father, a man of property, beftowed great care. In the year 1764 , the French government having propored as the fubject of a prize of 2000 livres the beft method of lighting the freets, the prize was divided among three artifts who had made experiments on the fubject; but Lavoifier, who had examined it as a philofopher and man of letters, was rewarded in a different manner. The paper which he wrote in anfwer to this quettion was publifhed at the expence of the Academy of Sciences, and the King caufed a gold medal to be prefented to him by the prefident in a public fitting of the academy held on the gth of April 1766. This paper, which contained a great many excellent mathematical and philofophical obfervations, announced the author's entrance in the career of fcience in which he afterwards continued to diftinguith himfeif.

On the 18 th of May 1768 , he was chofen a member of the academy, in the room of Baron; and about the fame period he publithed feveral treatifes in different periodical publications, 
tions, fuch as Obfervations on the propofal for erecting a fteam engine to fupply the city of Paris with water, on thunder, on the northern lights, on the tranfition of water ints ice, \&c. The Memoirs of the Academy for the year I770 contain Obfervations by him on the nature of water, and on the experiments faid to prove the poffibility of its converfon into earth. Lavoifier, however, fhowed that the earth obtained by the ditillation of water was a part of the veffes which had been attacked during the operation: for, having continued the diftillation without interruption ror days, the total weight of the veffel and of the water contained in it remained unchanged, but the pelican had loft as much in weight as the water had increafed.

In the year 1774 Lavoifer proved that the increafed weight of metals during their oxidation, arofe from their imbibing the air contained in the veffels in which the operation was performed; by which means a queftion that had long formed a fubject of difpute among philofophers and chemifts, and had occafioned many coftly experiments, was finally determined. This formed a foundation for his new chemical theory, which he firft oppofed to the phlogific fyftem before adopted by chemilts.

In the fame year he publifhed his fmall phyfico-chemical works. Prieftley, in the year 1772 , had made known his experiments on carbonic acid gas; but Lavoifier traced back its origin to Paracelfus, born in 1493 , and to his pupil Van Helmont, born in 1588 ; and howed that even Paliffey, Ray, Boyle, Hales, Venel and Macbride had been in part acquainted with this gas. He howed alto that Dr. Black of Edinburgh had called the attention of philofophers to this important part of chemiftry fo early as the year $175^{*}$; and therefore he afcribed to him the honour of this new difouvery, which in the courfe of twenty years had given occafion to fo many others of the utmoft importance to mankind.

Lavoifier proved by his experiments, that an elattic fluid, or kind of gas, was united in a lixed form with calcareous earth; he proved the prefence of it in alkalies, and howed

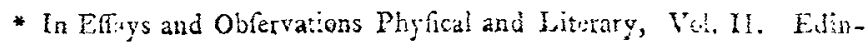
burgh I:56\% 
that it was produced during the reduction of metallic calces and of the phofphoric acid. He not only applied to chemittry the different methods of experinental philofophy, and its various kinds of apparatus, but even introduced into it the fpirit of accuracy and calculation, which had never before been employed in that way With this union of two branches of natural knowledge, Lavoifier's principal work forms the commencement of a bright period in the hiftory of their improvement.

Prieftley having found that, during the union of nitrous acid with an earth, oxygen gas was generally produced, thence concluded that atmofpheric air was a mixture of nitrous acid and earth. Lavoifier, on the contrary, howed in the year $177^{6}$, that oxygen gas was a component part of nitrous acid. This obfervation confirmed the truth of a great number of experiments, and gave rife to a variety of other difooveries.

In the year 1778 he was able to prove that the pureft air, that neceflary for refpiration, or the dephlogifticated air of Priefley, was the caufe of acidity, and exifted in all acids. To this part of the atmofphere, contained in all acids, which converts the metals into metallic calces, and creates oxygen gas in union with caloric, he gave the name of oygen.

In Germany, where chemiftry has been much cultivated, this theory was foon adopted, and firt made known by Girtanner at Gottingen, and Hermbftadt at Berlin, the latter of whom tranflated Lavoifier's Elementary Treatife of Chemiftry into German. Soon after it was adopted alfo by Klaproth, Alayer, Lichtenberg, and Göttling. Wetrumb, Crell, and Gren, however, ftill endeavoured to defend the old phlogiftic fyftem; but the majority was againft them. Berthollet remained for fome time undecided; but his own experiments foon induced him to embrace this theory, which condusted him to important difcoveries.

In the month of June 1783 , Lavoifier conftrueted an apparatus for burning hydrogren gas with oxygen gas in clofe veffels; and the refult was a thuid, or rather pure water, the weight of which correfponded exactly with that of the two gafes employed. Having learned that the fame cxperiment had becu made by Cavendith and Monge, he inverted an- 
other apparatus for decompofing water, with which, by means of iron tubes, he feparated the hydrogen from the oxygen. Lavoifier proved alfo that atmofpheric air confifts of two kinds of gas, one of which is fit, and the other unfit, for refpi. ration; that the firft is oxygen, which poffeffes the property of uniting with bodies, and thereby becoming fixed; that this fubftance combines with metals during their oxidation, and with combuftible bodies when in a ftate of combuttion; and that in the firft cafe a metallic calx is produced, and in the laft an acid, which is of a different nature according to the kind of the inflammable body. On this depends the whole theory of combuttion, of the production of acids, and the divifion of natural bodies into inflammable and noninflammable. On this depends alfo the knowledge of that kind of gas called formerly fixed air, but now carbonic acid gas, becaufe it is produced during the combuftion of charcoal, and is compounded of carbon and oxygen.

Lavoifier, therefore, was the firft who difcovered that the different kinds of gas are the refult of the folution of any fubftance by caloric; this conducted him to the conclufion that the caloric and the matter of light, difengaged during the combuttion of inflammable fubftances, does not arife from them, but from the air which furrounds them, and in which the combuftion takes place. In this feries of experiments may be claffed that made by Lavoifier on detonation, which is nothing elfe than a fudden inflammation, the products of which are difengaged in the gafeous form.

In the year 1776 , Lavoifier by means of Turgot was appointed fuperintendant of the powder manufactory, in order to improve that art; and this he did fo effectually, that the powder manufactured under his infpection was capable of driving a mufket-ball to the diftance of 120 fathoms, whereas that made before was capable of driving it only to the diftance of 90 fathoms. In the war of 1765 , the Englith bullets reached our veffels from a diftance at which ours could not reach them; but in the war of 1778 the cafe was reverfed. In the year 1788 he was in great danger of lofing his life in confequence of an explofion which took place during fome experiments then made at Effone.

VoL. IX.

$\mathrm{L}$

All 
All thefe expcriments conducted him to a complete analyfis of nitrous acid, an acid eafy to be decompofed, but difficult to be extricated ; and which, however, is of great importance, as it is a component part of faltpetre, and at the fame time of gunpowder.

In the year 1789 , Lavoifier endeavoured to bring the whole feries of his experiments into fyftematic order, and thence to compofe an elementary work on chemiftry. 'Two editions of this work were fold off in the author's lifetime, and he had begun to prepare a new and improved one, in which new light would have been thrown on the whole fcience of chemiftry. He intended alfo to give a collection of all his Eflays in fix volumes, but of thefe three only were publifhed.

It would be difficult to determine what influence Lavoifier's difcoveries have had, or may in future have, on the practice of the arts; but, if we confider the entire revolution effected in that of dyeing by the new chemiftry, we thall find reafon to entertain the beft hopes refpecting the reft. Almoft all the phænomena in this art may now be traced hack to burning. and combuftion, as has been fufficiently proved by Berthollet in his important work on dyeing. This art, therefore, which formerly depended on mere practice, is now founded upon a very fimple and well-grounded theory.

The art of mining, of aflaying and fuling metals, of preparing fteel, of bleaching linen and wax; in a word, almoft all the chemical arts, under the direction of the new theory have been rapidly improved and brought near to perfection.

By applying thefe difcoveries to the phenomena of breathing, Lavoifier has fhown that this vital function is a real combuftion of carbon and hydrogen, by which carbonic acid and water are produced. The effect of this combunion is animal heat, the degree of which he was fo fortunate as to afcertain by calculation. His experiments on this fubject conducted him to means for determining the remarkable relation which exifts between accelerated refpiration, the circulation of the blood, and perfpiration, and between the different powers, and the application made of them by nature. He had laboured alfo for a long tine on a particular work on the fubject of digeftion. 
The laft, and perhaps the moft important of Lavoifier's labours related to animal perfpiration, on which fubject he read a paper before the Academy of Sciences on the $4^{\text {th }}$ of May x $79 \mathrm{r}$. A part of this paper may be found in the Memoirs of the Academy for the year 1790 .

Lavoifier firft lays it down as an eltablifhed principle, that the animal body is maintaincd by refpiration, perfpiration, and digeftion. He then examines in a chemical view each of thefe effects, the nature of the peripiration of the fkin and of the lungs, diflinguifhes the effeets from each other, and, as it were, interrogates nature refpceting the three caufes by which they are produced. He invented an apparatus by which every thing that relates to evaporation externally, and to breathing internally, could be obferved. In conjunction with Seguin, he made on this fubject fome exceedingly difficult and laborious experiments, by which he found that $\mathbf{a}$ man by perfiration lofes daily 2 pounds 13 ounces; that in the courfe of 24 hours he confumes 33 ounces of oxygen gas; that in the fame period 8 cubic feet of carbonic acid gas, one third of which confifts of carbon, and two thirds of oxygen, are difengaged from the lungs; that the quantity of water produced in the lungs amounts to 1 pound 7 ounces, of which 3 ounces are hydrogen, and 20 oxygen, and that only 6 ounces of water are formed by the perfpiration of the lungs. For thefe experiments he had provided balances which did not err half a dram in 125 pounds.

By thefe accurate and difficult experiments Lavoifier had obtained great infight into the caufes of feveral difeafes, as well as in regard to the means of affifing the powers of nature in curing them, and on that account had refolved to overturn the immenfe coloffus of medical prejudices and errors which had been before eftablifhed. None of his undertakings was of more importance than this, and it is much to be lamented that he did not live to carry it into execution.

Between the years $x_{77}$ and ${ }_{17} 85$, he improved and cultivated at his own expenfe 240 acres of land in la Vendée, in order that he might promote agriculture by fetting a good example before the farmers; and his mode of culture was attended with fo much fuccefs, that he obtained a third more L 2 of 
of crop than was obtained by the ufual method. In the courfe of nine years his produce was doubled; but as the capital he laid out did not produce him five per cent., he was thence induced to form a plan for lowering the intereft of capitals, and extending leafes to the period of 27 years.

The committee of the conftituent affenbly of 1791, appointed for the purpofe of fettling the taxes, having requefted Lavoifier to affift them by his knowledge in accomplifhing the object which they had in view, his ideas were of great affifance to them in the formation of a plan by which the whole fyftem of income and expenditure was greatly fimplified. In order that he might give the committee the necerfury information on this fubject, he communicated to them an extract from a very large work on the different productions of the country, and their confumption, for which he had been long employed in collecting materials. This extract was printed by the National Affembly, under the title of Ricbiffes territoriales de la France, and is undoubtedly the beft work on the fubject.

In the year I79I he was appointed a commiffioner of the national treafury; and, without abandoning the ftudy of the fciences, he introduced into this department fuch order and regularity, that the proportion between the income and the expenditure in all the branches of government could be feen at one view every evening.

In the great and important undertaking of eftablifhing in France a new fyftem of weights and meafures, with which the acadeny had been occupied for fome time, none of the niembers was more active or more ufeful than Lavoifier.

In order that he might diffufe new light on the important but not fufficiently illuftrated doctrine of the expanfion of netals by heat, he conftrueted an apparatus by which metal rods immerfed in water and expofed to different degrees of heat, put in motion a telefcope, which fhowed on a diftant object the fmalleft degree of expanfion.

In the year 1793 , it being neceffary to have a bafis meafured with the greatef accuracy, in order to determine the length of an arc of the meridian, he erected in his garden rods of platina and copper, which he employed as metallic thermoneters, 
thermometers, and on which each degree of variation in the temperature could be accurately obferved. On this occafion he afcertained the proportions of their expanfion, and thefe rods were afterwards employed in meafuring a bafe between Lieufaint and Melun; from which were afterwards deduced the length of the meridian between Dunkirk and Barcelona, the circumference of the earth, and the ftandard for the new French meafures.

It might have been expected that a philofopher poffeffed of talents fo rare and uncommon, would have infpired with refpect for his character the moft favage and worthlefs of mankind. But at that period the helm of the French government was in the hands of a fet of monfters to whom nothing was facred, and whofe unbounded ambition facrificed every thing to the hope of flattering the deluded populace. They conceived that nothing could contribute more to the accomplifhment of this view, than to offer up as victims at the thrine of popular licentiounefs all the farmers-general; and in confequence of this cruel meafure, twenty-eight of them, among whom was Lavoifier, were put to death, for crimes real or pretended, on the 8th of May 1794, by the bloody revolutionary tribunal.

In the year 1771 , Lavoifier married Mary Anne Pierette Paulze, the daughter of one of the farmers-general, a lady of agreeable manners, and poffeffed of confiderable talents. She engraved the copper-plates for his laft work.

Lavoifier was of large ftature; complacency and penetration were difplayed in his countenance; his behaviour was mild, civil, and polite; and his activity knew no bounds.

X. Proceedings of Learned Societies, Mifcellaneous Articler, and new Publications. Feb. 1801.

ROYAL SOCIETY OF LONDON.

J AN. 29. A paper on a moft remarkable lufus of a theep, by Anthony Carlifle, Efq. was read. Alfo an anatomical paper on a Rhinoceros, by Mr. Leigh Thomas. 